\title{
The Influence of the Actor Network on the Innovative Process of Transgenic Soybean in Rio Grande Do Sul, Brazil
}

\author{
Doriana Daroit ', Luis Felipe Nascimento ${ }^{2}$
}

\begin{abstract}
Rio Grande do Sul was the first Brazilian state to plant genetically modified soybean. The sowing occurred in 1998 with Roundup Ready soybean seeds from Monsanto smuggled from Argentina. The aim of this study is to investigate how this innovative process of planting transgenic soybean came about in Rio Grande do Sul based on the actor network involved in the period 1998 to 2003. Although the innovative process has been discussed in the literature on innovation management since the work of Schumpeter, there is still no clear understanding of the issues of interests and power that involve the innovative process. Given this, from within the literature we have sought a perspective that would understand the innovative process as being political. We adopted Actor Network Theory as a base for the discussion of the primary and secondary data obtained regarding the controversy surrounding transgenic soybean in RS. The results point to the existence of two translation chains that contribute towards the formation of actor networks.
\end{abstract}

Key words: Actor Network Theory; transgenic soybean; GMO.

\footnotetext{
I ADM/FACE/UnB - ICC Ala Norte - Campus Darcy Ribeiro - Brasília/DF, Brazil. Phone: +55 6I 33072343. E-mail: doriana@unb.br

2 PPGA/EA/UFRGS - Rua Washington Luís, 855 - Porto Alegre/RS, 900 I0-000, Brazil. Phone: +55 5I 330838 I4.

E-mail: nascimento@ea.ufrgs.br
} 


\section{Introduction}

The literature on the generation and spread of innovations that was developed from the work of Schumpeter considers the firm the locus of innovation and responsible for economic and technological development. In order to occur, the innovative process, though internal to the firm, requires the presence of external elements. The study of the role of institutions in the innovative process originally focused on the science and technology systems (Freeman, 1982) and was extended to the study of national systems of innovation (Freeman \& Soete, 1997; Nelson \& Rosenberg, 1993; Lundvall, 1999). Hence, the innovative process is understood to occur in a defined and mutant social space.

Within this social space, the relationships established between the actors involve economic, political, scientific, historical, ecological and cultural issues that represent the full complexity of the environment in which the innovations are generated and diffused. As Dosi, Levinthal and Marengo (2000) said, the traditional literature on innovation management ignores issues such as incentives and power that influence the innovative processes. In addition, as pointed out by Lundvall, et al. (2002), up to now, the concept of a national system of innovation has failed to fully explain the interaction between the diverse external and internal elements of the firm and no studies have been developed into the influence of issues of power on the innovative process (Lundvall, 1999; Lundvall, et al. 2002).

The complexity of the context within which the innovative process occurs involves innumerous actors whose relationships produce specific local conditions that are important when attempting to understand the generation and spread of innovations. This becomes even more important when this context is located in developing countries, like Brazil, with a history of technological dependence that has influenced its process of development (Furtado, 2008). We begin with a case study of the transgenic soybean in Rio Grande do Sul (RS), Brazil and study the relationships existing between the actors and their influence on the innovative process. We chose this case because it had local, national and international repercussions, as it was fundamental in defining the legal framework regarding genetically modified organisms (GMOs) in Brazil, as well as having economic effects, since the country is the second largest exporter of soybean in the world. Therefore, the question guiding this study is: Considering the network of actors involved, how did the innovative process related to transgenic soybean take place within Rio Grande do Sul?

To answer this question, we procured a literature capable of aiding the understanding of the specificities of the case of transgenic soybean in RS, such as the smuggling of the seeds, the technological dependence in relation to the development of the transgenic seeds and the political discourse adopted by the actors involved. It was decided to use an approach based on Actor Network Theory, with the aim of offering a perspective that deals with the actors not only as economic, but also as political, social, historical and environmental agents so as to understand the innovative process that occurred in RS and its consequences with regard legislation and the GMO market in Brazil.

\section{Method}

The guiding principles of this study are:

- The actors are engaged in controversies that define the course of action.

- The actors are, in reality network-actors, since they do not act alone.

- The actor network is not previously established, it is constructed by the actors that interfere in the course of the action. Hence, the network is the result of the analysis.

- The network-actors may defend different perspectives, so constituting other networks that are intertwined and contribute towards the development of controversy.

In order to put these principles into operation, the keycategory considered in the analysis is controversy. The controversy over GMOs was chosen because it involves new ethical issues regarding their creation, development on an industrial scale and marketing. Transgenic soybean, in turn, is inserted in a complex mesh of relationships of production and marketing, which construct the nature-culture collective both locally and globally. 
In an attempt to obtain a multi-voice understanding of the subject, the materials listed below were chosen for analysis:

- Scientific articles and books: The articles and books were selected because the represent examples of texts in favor and against the sowing and consumption of GMOs.

- Legislation: Since 1995 there have been laws that deal with research into GMOs and their testing and marketing.

- Sites of actors involved in the controversy: Research into the sites of actors was carried through Google using the expressions: transgenic soybean, transgenic soybean in the RS and Roundup Ready soybean, and other sources that they mentioned, constituting a set of local, national and international actors. Some of these sites were previously selected, other were encountered during the course of the field work, especially with the use of the mapping software Issue Crawler.

- News reports: The two main newspapers from Rio Grande do Sul are the Correio do Povo and Jornal Zero Hora (ZH) According to Heberlê (2005) the Correio do Povo offers quite short news reports. Hence, priority was given to the reports in the supplement Campo \& Lavoura (Field \& Crop) in Jornal Zero Hora, since $\mathrm{ZH}$ often includes the voice of the interviewees, so providing a better understanding of the context in which they were given. The news reports used cover the period from February 1998 (chosen because it was the first report of the illegal sowing of transgenic soybean in RS and is considered the spark behind the controversy as it brought the issue to public awareness) until $3 / / / 2 / 2003$, the year in which the first Provisionary Measure (PM) was issued allowing the trading of the transgenic crop.

- Individual Interviews: The interviews were held in March and April of 2007 with researchers working with transgenic soybean. We gave priority to the researchers (for and against GMOs), due to the central role of these professionals in the construction of scientific fact. The interviewees were: a researcher from State Environmental Protection Agency (Fundação Estadual de Proteção Ambiental - FEPAM) and the Zoo-botanical Foundation of RS, a professor and researcher form the Genetics Department of the Federal University of Rio Grande do Sul (UFRGS) and a professor and researcher from the School of Agronomy at UFRGS. The researchers are recognized in the scientific community, as well as acting to raise awareness of GMOs within society. Besides identifying the world view, position and trajectory of these researchers, the interviews were intended to identify actors that supported and opposed them during the controversy, so extending the possibilities of investigation into the construction of the network.

Following the above set of principles and data sources, blow we present the constitution of the transgenic soybean actor network in RS in the period from 1998 to 2003.

\section{Results}

To better understand the formation of the network in the controversy surrounding the transgenic soybean in RS, the main actors involved are in introduced, with emphasis on their positions and influence so as to characterize their role during the course of the controversy.

\section{The transgenic soybean sown in RS}

The deoxyribonucleic acid (DNA) recombination technique led to the first Genetically Modified Organism (GMO) in the 1980s, human genes were added to E. Colli in order to produce insulin (Mortari, 2006). In 1988, two articles were published in Nature Biotechnology on the production of transgenic soybean: Production of transgenic soybean plants using Agrobacterium-mediated DNA transfer (Hinchee, et al. 1988) and Stable transformation of soybean (Glycine max) by particle acceleration (McCabe, et al. 1988). As from 1988, companies began to patent their techniques: Monsanto - Agrobacterium, Agracetus - particle acceleration and DuPont - direct gene transfer.

In 1996, Monsanto became the first company to put soybean seeds, Roundup Ready soybean (RR), which is resistant to glyphosate on the market. The RR soybean seeds were mainly sown in the USA and later sold to other countries between, among them Argentina, one of the three biggest soybean producers in the world. At that time, Monsanto had seeds undergoing testing in research fields located in RS. Other research centers, like the 
Empresa Brasileira de Pesquisas Agropecuárias (Embrapa) and biotechnology laboratories at UFRGS were also making strides in the genetic manipulation of vegetable species using non-traditional methods.

Soybean occupies the second position in terms of global market value of grains (almost 3 billion dollars), and Brazil is the second largest producer (around 60 million tons) after the USA (around 87 million tons). In 1997, 6 countries grew genetically modified plants: the USA, China, Canada, Australia and Mexico. The area planted with has increased at around $13 \%$ per year, surpassing 100 million hectares in 22 countries (James, 2006).

Rio Grande do Sul was the first state in Brazil to plant genetically modified soybean (Sousa Jr. 2006). The transgenic soybean planted in RS is RR soybean, the property rights of which belong to Monsanto. Besides the RR soybean seed, Monsanto also sells the glyphosate-based herbicide.

\section{The soybean farmers}

In February 1998, the first reports appeared in the press that transgenic soybean, using RR seeds smuggled from Argentina, was being sown in the north of RS. The planted area was believed to be 7.500 hectares ( $\mathrm{ZH}, 05 / 02 / 1998)$. This fact sparked the transgenic soybean controversy in RS, because it brought the illegal sowing of transgenic seeds to the attention of the public.

The farmers justified sowing the crop by saying they believed that the transgenic seed offered higher productivity and reduced production costs, especially because less herbicide would be needed. Through their representative entities, they organized demonstrations in the north and center of RS, which brought together hundreds of farmers with their tractors calling for freedom of choice for their plantations: transgenic, conventional or organic ( $\mathrm{ZH}, 12 / 03 / 2002)$, as a means of pressuring for a lifting of the ban on the cultivation of RR soybean.

However, not all the farmers followed the same path. At the $10^{\text {th }}$ National Soybean Forum, held in Porto Alegre, the purchasing director of a French cooperative - Coopèrative Agricole Noelle Artemis - said that the French would buy conventional soybean if its price was no more than $5 \%$ higher than the market value and the traceability of the product was guaranteed (ZH, 04/05// 999). With a view to meet the demand from this market, the Cooperativa Agropecuária do Alto Uruguai Ltda. (Cotrimaio) created the non-genetically modified soybean program and organic production program, the traceability of which met European standards. From 1998 to 2006, Cotrimaio increased its revenue fourfold, becoming the second largest agricultural cooperative in RS.

\section{Monsanto}

The soybean seed market is dominated by multinational companies and has been undergoing a process of concentration, especially with the commercialization of transgenic soybean. In the period from 1995 to 1998, around 50 acquisitions and mergers were recorded, reaching a value of US\$17 billion. Other forms of contract and joint ventures reached a value of US $\$ 13$ billion in the same period (James, 1998). Monsanto was involved in more acquisitions and alliances than any other company. The first company to be acquired by Monsanto was Agracetus. Another acquired company was Asgrow Seeds, with which Monsanto jointly developed Roundup Ready soybean, which is resistant to glyphosate. By acquiring these two companies, Monsanto ensured the technological domination necessary for the production of transgenic seeds. With this process of concentration Monsanto became the largest seed company in the world. In Brazil, Monsanto acquired Agroceres, the largest Brazilian corn seed company, with $30 \%$ of the market (Kleba, 1998).

In June 1998, Monsanto formally requested the commercial release of RR soybean before the National Technical Commission on Biosafety (CTNBio). Until the CTNBio granted the commercial release in September, Monsanto appeared to be a somewhat neglectful actor in the controversy. With the exception of possible accusations made by the Federal Police in relation to the illegal plantation of RR soybean and the possible hiring of a firm of private, Monsanto was rarely mentioned and apparently inactive before the general public, with few statements from its Regulation Director regarding the accusations in the case of illegal dissemination of seeds ( $\mathrm{ZH}, 06 / 02 / 1998)$. This changed radically with the release of RR soybean. 
Soon after the commercial release, the $\mathrm{ZH}$ supplement Caderno Campo \& Lavoura published a two-page interview with a representative of Monsanto (the name of the interviewee was not given), the title of which was Uma supersafra de dúvidas ( "a bumper harvest of uncertainty) (ZH, 02/10/1998). In this interview, Monsanto answered questions from the soybean farmers regarding productivity, the use of herbicide, environmental and health problems, monopoly formation, the market for transgenic crops, prices and costs, and the commercial launch of the RR seed. Monsanto strongly recommended that the farmers should not store seeds for the next sowing, in order to avoid a drop in productivity. In order to deny all possible problems, the CTNBio report was cited several times in the text. This discourse was in direct response to the arguments of some researchers and agronomists that there were no conclusive tests available on the effects of transgenic soybean on health and the environment. The manifestations from Monsanto were based on the technical report from the CTNBio, and were intended to dissipate the doubts raised by non-governmental organizations (NGOs) regarding the data presented.

In 2003, after the permission for the sowing and commercialization of RR soybean was granted, Monsanto began to charge royalties. As royalties can only be charged upon presentation of a legal invoice for the sale of the seeds, in this case their collection was unfeasible since the seeds were illegal. Nevertheless, the farmers' representatives and Monsanto entered into an agreement in RS: Instead of paying royalties on the seed, the farmers would pay on the harvest.

\section{The governmental actors}

Due to pressure from the farmers and their associations in RS, the governmental actors were very active during the analyzed period of the controversy. At the Federal level, debates were centered in the ministries and in the CTNBio.

\section{- National Technical Commission for Biosafety - CTNBio}

The CTNBio was created in 1995 by the Law nr 8.974 (Biosafety Law). Its purpose is to provide technical and, support and advice to the federal government on the formulation and implementation of the National Biosafety Policy in relation to GMOs, as well as establish guidelines and reports for the construction, experimentation, cultivation, manipulation, transport, commercialization, consumption, storage release and disposal of GMOs and their derivatives. The CTNBio is composed of 27 members, with 9 representatives from ministries and the remaining specialists from different areas of knowledge related to biotechnology (CTNBio 2009).

At the beginning of 1998, when the RR soybean was being planted, the law only allowed the plating of GMOs for the purposes of research and controlled tests. Therefore, both the smuggling of RR soybean seeds and their sowing were illegal in Brazil according to the Biosafety Law. However, the property rights of Monsanto over RR soybean were guaranteed by Law 9.456, 25/04/1997 (Cultivar Protection Law). In the case the ban on planting GMOs was lifted, the sowing of RR soybean would involve paying royalties to Monsanto.

On the occasion of the request made by Monsanto to lift the ban on the commercialization of RR soybean, the Federal Court in São Paulo conceded an injunction suspending the cultivation of RR soybean in the absence of environmental impact studies in response to requests made by the Consumer Defense Institute (Instituto de Defesa do Consumidor - IDEC) and environmental groups, among them Greenpeace. In September 1998, the CTNBio approved the release of RR soybean without the need for environmental impact studies conducted by an independent entity, and accepted the results presented by Monsanto in reference to the USA. However, the sowing was still to able to reverse the judicial actions.

\section{- The ministries}

The most active ministries in this controversy around the RR soybean were the Ministry of Science and Technology (Ministério da Ciência e Tecnologia- MCT) and the Ministry of the Environment (Ministério do Meio Ambiente - MMA). They found themselves on opposite sides of the debate. The MCT took a position in defense of biotechnology and the GMOs, since they are seen as representing economic and technological development for the country, as a biotechnology policy was necessary in order to permit the insertion of Brazil in such a promising field of knowledge. 
For the Ministry of Science and Technology: “- When the evaluation of scientists came to be contested by consumers and environmentalists, we were confronted by an attack on science itself. We faced a new obscurantism" (ZH, 22/07//999). For its part, the MMA, were opposed to the GMOs, and focused on the need for more studies. With regard biosafety and the legislation, the MMA followed the Precautionary Principle and open access information policy (MMA, 2007).

The confrontation between the two ministries continued in the following years due to the discussion about the reformulation of the Biosafety Law in 2003. The MMA proposed 15 vetoes to the bill based on unconstitutionality and the public interest (MMA/Consultoria Jurídica, 2005), with only two being accepted in relation to length of time available for the assessment of the processes submitted to the CTNBio (Home Office - Undersecretary for Legal Affairs (Casa Civil/Subchefia para Assuntos Jurídicos, 2005)).

\section{- Legislative Assembly of RS and the State Secretariats.}

The Agriculture, Livestock and Cooperativism Commission of the Legislative Assembly argued that, in the case that commercial plantations of transgenic soybean existed in RS, they should be preserved and the harvest commercialized, since the farmers could be the victims of smuggling and should not have to suffer with the loss of the harvest, or, in the words of the president of the Commission: "That's why the onus should not be met by the farmer, who seeks to reduce the cost of production" $(\mathrm{ZH}$, 19/02/1998).

In January 1999, with the election of Olivio Dutra, the Workers Party (Partido dos Trabalhadores) assumed the government of RS, while also increasing its share of seats in the Legislative Assembly. After this, a state deputy with the backing of the Secretary for Agriculture presented a bill intended to impede the cultivation and sale of GMOs, and so make RS into a "State free of transgenics". The justification for the law was grounded in the uncertainty regarding the effects of transgenic crops on the environment and health, as well as the possibility of obtaining economic gains with the sale of conventional soybean to the European Union. This position was a relief to the pro-family farming movement in the RS, which had re-emerged in the 1970s and struggled for the autonomy of the small rural producer.

With the election of the Governor Germano Rigotto in 2003, the government of RS assumed a pro-transgenics position. According to Germano Rigotto: “- There is transgenic soybean in every producer State. If an illegal situation exists, then all such States are in that situation, not just Rio Grande do Sul." (ZH, 09/03/2003). Hence, the state government assumed that the cultivation of RR soybean was inevitable.

\section{- The Presidency of the Republic}

In 2003 the mandate of Lula in the Federal Government began. During the presidential campaign Lula's team proposed a ban on the cultivation of transgenic soybean, since there was a market for conventional soybean, which was understood as a differentiated product. However, in March the first provisional measure (PM) was issued for the commercialization of the transgenic soybean crop, due to the great pressure from farmers' representatives. PM II 3 authorized the commercialization of the crop that had been harvested in that period and determined the destruction of transgenic grains and seeds by the end of 2004.

In 26/09/2003, the government issued PM I 3 | on the lifting on the ban on the sowing of modified soybean seeds in the harvest 03/04 for those farmers that had seeds in stock. PM I 1 | required that farmers who planted RR soybean in the 03/04 sign a Term of Commitment, Responsibility and Adjustment of Conduct. The document provoked heated debate in the National Congress, as some members alleged that it treated the farmers with transgenic seeds as criminals. Furthermore, they argued that inspection would be impossible ( $\mathrm{ZH}, 26 / 09 / 2003)$. The term contained a section in which the signee declared that he was aware of the illegal nature of the crop. This PM practically closed the controversy regarding RR soybean, since the farmers felt they were free to plant the transgenic seeds and demanded successive Provisionary Measures for the commercialization of the transgenic crops and the Monsanto began to charge royalties. 


\section{Researchers and research institutes}

\section{- Embrapa}

Since the 1970s, the Brazilian Agricultural and Livestock Research Company (Empresa Brasileira Pesquisa Agropecuárias - Embrapa) has acted in the adaption of soybean varieties to Brazilian climatic and geographical conditions, having produced significant results at the end of the 1980s (Embrapa Soja, 2003). In the 1990s, Embrapa, lacking sufficient logistical, financial and human resources to meet the needs of the national productive sector, created the Embrapa Partnership System. To begin with, partnerships with public research institutions were prioritized. Later, partnerships were also established with the private sector, especially representatives of the seed industry. The agreements allowed for the participation of Embrapa's partners in the rights to the cultivars generated as a result of joint research programs, which also implied the rights to multiply, commercialize and earn royalties (Miranda, 2005).

At the end of the 1990s, Embrapa adopted a market oriented position, inline with the national interests regarding property rights over genetic material, in order to protect the genetic material developed in its research centers. Embrapa is placed in $4^{\text {th }}$ place in the market of soybean cultivar ownership. In 1998, the president of Embrapa expounded a pro-transgenic position at the largest agricultural fair in the South of Brazil, confirming the existence of a partnership with Monsanto to develop genetically modified soybean seeds.

\section{- Researchers}

In order to express the positions of the researchers involved with GMOs we present some studies recommended by the interviewed researchers. In 2006, the International Service for the Acquisition of Agrobiotech Applications (ISAAA) issued a report highlighting the benefits of planting transgenic crops, which considered data from 1997 to 2005 (Brookes \& Barfoot, 2006). The advantages identified are higher productivity, reduced costs and lower consumption of herbicides. The report from the Nuffield Council on Bioethics (2003) states that the benefits for developing countries may be greater than those for developed countries. GMOs represent a possible solution to the problems of high rates of poverty and the unsatisfactory state of health and of agricultural sustainability, because of the possibility of generating higher income and reducing environmental impacts. Hence, the cultivation of form would bring benefits for the environment due to the reduction in the use of pesticides, guarantee food security and, furthermore reduce production costs.

However, pro-transgenic studies are countered by a series of others that cast doubt on the results obtained, and call for direct studies with soybean and not with other plants and bring new data and new interpretations (Nodari \& Guerra, 2000, Patel, et al. 2005, Kleba, 1998, Pelaez, et al. 2004; Watanabe \& Nutti, 2002). The studies that are opposed to the GMOs highlight the importance of the risks to health and the environment, and question the cost reduction obtained with GMOs, as well as the research strategies that undervalue other forms of agriculture such as agroecology. Moreover they question the role of Monsanto in the dissemination of transgenic crops.

The interviewed researchers, besides carrying out research with GMOs were very active in the controversy regarding RR soybean. They took part in debates organized throughout RS in universities, unions, associations, on radio, television and in the Legislative Assembly, so popularizing the scientific knowledge about GMOs and the RR soybean.

Both the Genetic researcher and the Agronomy researcher from UFRGS work in the development of transgenic seeds. The geneticist's research group uses the gas particle acceleration technique. There is no need for the payment of royalties since an American professor made a drawing of the particle accelerator that was passed on to the researcher and built in the Physics Department of UFRGS. However, her concern in relation to royalties is with the gene used in the research: The most recent work of the group uses the Bt gene, which is resistant to insects. This gene was modified by a Canadian professor and the Brazilian researcher, in conversation with the professor, negotiated transfer term that allows the group to carry out research with the gene without paying royalties. Furthermore she believes it is of utmost importance to carry out research with transgenic soybean and remain autonomous in relation to the multinationals: "I 
hear: - You are a competitor of Monsanto! I say: Yes, I am! It is extremely important! (...) We're not going to be dependent on multinationals to develop our research."

The discourse of the researcher from Agronomy follows a similar line: "[The multinationals work in large cultures that have large markets, And in the tropics, what do they do? This is the chance for us to work on things of interest to the Brazilian people. I have always defended biotechnology in this." The interviewee is part of a research group that has patents for varieties of transgenic oats, and the main variety of oats planted in Argentina is produced by the group.

The researcher from the FZB, who holds an antitransgenic position, defends an attitude she refers to as ethical in relation to GMOs and their effects on the environment and human beings: "I don't want to be a guinea pig". For this, she bases here position on scientific studies whose results cast doubt on the advantages of transgenics.

When questioned about the debate on the pros and contras of transgenics, the geneticist states that: "in the beginning, what we wanted was to place one against and one in favor. So I argued with members of landless groups, land squatters, with environmentalists. It was terrible, because we are not speaking the same language!" The two researchers from UFRGS stated they began to avoid participating in public debates, a frequent quote from both of them being "it's a waste of time". On the other hand, the interviewee from the FZB claimed that the pro-transgenic actors abandoned the dispute out of fear of losing and because they were unable to present research results that prove transgenics do no harm to health or the environment. Moreover, she classified the pro-transgenic position as ideological and directed towards the interests of the multinationals. The researchers from UFRGS used similar arguments. For them, the discourse against transgenics has no scientific base. In the words of the professor from Agronomy: "what happened at that time continues to happen now: the scientific debate is abandoned in favor of an ideological one."

\section{Non-governmental organizations (NGOs) against RR soybean.}

These organizations were active throughout the controversy, especially at demonstrations and in legal processes aimed at impeding the lift on the ban of RR soybean. The most active NGO was Greenpeace, which was responsible for demonstrations in RS an in Brasilia on the event of CTNBio meetings. Greenpeace acted together with the Consumer Defense Institute to file a public civil action that impeded the planting of RR soybean even with the favorable report from the CTNBio.

Another organization that actively participated in the controversy was the Landless Workers Movement (MST). One of the most important episodes in the controversy happened during the World Social Forum in 200I, held in Porto Alegre, RS. During the Forum, members of the MST and the French farmer José Bové took part in the destruction of 2 hectares of corn and soybean belonging to Monsanto in RS (ZH, 20/0I/200I).

\section{Discussion}

As stated in the Introduction, in order to understand the innovative process a being political and influenced by vested interests and power relations, Actor Network Theory was used as a base for the discussion.

The actors introduced herein correspond to what Latour (2006) calls obligatory passage points, that is, indispensible actors that are converted to obligatory quotations or essential laboratories in the unfolding controversy. These actors are fundamental for the definition of the paths of the innovative process, since they need to be mentioned by other actors when they adopt a position in relation to the controversy (Law, 1986). Therefore, the obligatory points of passage define translation chains that link the innovation produced in the laboratory, in this case the RR soybean, to the market and society.

Callon, et al. (200I) claim that the constitution and functioning of the networks can be understood by analyzing the translation operation. The translation is the interpretation given by those that construct the scientific facts - soybean - from their interests and from those people that they recruit (Latour, 2005). Each obligatory point of passage has a set of allies that support its interpretation and help from the network within which the controversy occurs. Since they do not act alone, the actors can be understood as network-actors (Latour, 2006). 
When analyzing the positions adopted by the actors in the case of RR soybean in RS, innumerable translation chains can be seen supported by different actors that define the result of the innovative process, that is, the release for planting and commercialization of the RR soybean. The strongest translation chain within the network is that which allies the development of research, planting and commercialization of RR soybean and the other GMOs to the technological and economic development of the country. This chain is expressed in the discourses of the farmers that to planted RR soybean illegally, given that they use arguments involving the increase in productivity and the reduction in production costs as justifications for sowing the crop. Besides the farmers, the reports from ISAAA and the Nuffield Council on Bioethics and Monsanto highlight not only the economic gains, but also the environmental conservation resulting from the reduction in the use of herbicides provided by RR soybean. The interviewed UFRGS researchers also supported this discourse, as well as introducing the issue of the mastery of genetic engineering techniques as a form of ensuring the technological competitiveness of the country. To these actors, it is possible to add the MCT and the government of RS during the office of Germano Rigotto. The latter, moreover, provided a discourse suggesting the inevitability of the planting of RR soybean, not only in RS, but also in other Brazilian states. Hence, RR soybean from Monsanto is converted into technological and economic development and environmental conservation for the country. Although this translation chain became hegemonic, it was not the only one to form the network.

In the midst of this chain an interesting point emerges: The Genetic researcher avoided paying royalties by means of direct and, in some cases, informal contacts with researchers from developed countries. Here it is possible to see another form of mobilization of allies for the constitution of obligatory points of passage. Latour makes no comment regarding this form. It constitutes an informal manner that the researchers have available to influence the course of action. The translation of interests is made by both the Genetics researcher from UFRGS, to whom the free drawing of the gas acceleration equipment was of interest, and the American professor for whom the dissemination of his work was of interest, since, in this way he would be able to acquire greater prestige. Perhaps this might be one of the ways that Brazilian researchers find to carry out their studies given the difficulties involved in doing such research in Brazil, be it due to the scarcity of funding and/or the limited research infrastructure of the universities that helps generate a scenario of technological dependence, especially in high technology sectors.

The NGOs, the studies that question the advantages of the GMOs and demand specific studies with soybean, the government of the RS under the direction of Olivio Dutra, the MMA and the interviewed researcher put forward an environmental/health discourse against transgenics that questions the risks and uncertainties in relation to the planting and consumption of RR soybean. These actors, at the end of the controversy, stopped being obligatory points of passage, given that these actors remained in a subordinate position in the relationships of power established in the network. Nevertheless, that does not mean that they were not fundamental for the controversy. An example of their importance can be seen by the fact that the ban on the planting and commercialization of RR soybean was only lifted by means of a Provisionary Measure in 2003, though the CNTBio had had approved its release in 1998. Another example of the importance of these actors was the organization of programs for conventional and organic soybean with the traceability of Cotrimaio. Even following market logic, the growth of Cotrimaio based on these programs demonstrated that transgenic soybean was not inevitable and that profitability and economic development can come from alternative sources.

These two main chains constitute the actor network of transgenic soybean in RS within which the controversy occurred. At first sight, each one of the chains appears to constitute a fixed and well defined network. However, the network is only constituted through the relationships (Descola, 2005) and thee relationships are movable (Calás \& Smircich, 1999), altering the position of the actors in the network. The network can only be understood as a whole or, as Law (2000) puts it, the network exploits relationships and, for this reason each actor can only be understood in terms of their relationships with the others. Hence, no network-actor can be understood as fixed. That is why, Latour (1997, 2004, 2005, 2006) and Löwy (2005) say that in order to understand the network it is necessary to follow the researchers while they develop their work, since it is from the generation of an innovation in the 
laboratory that the allies become mobilized, involving not only the scientists, but also profanes who are called to participate during the innovative process. In the case of RR soybean, the participation of the profanes occurred especially in the diffusion of the innovation, given that it was not produced in RS. Nevertheless, this participation and the constitution of the actor network support the view that the innovative process is a political process that goes beyond economic issues.

Hence, we believe that this study represents a contribution towards the understanding of the generation and spread of innovations as a political process that involves making choices between different world views and the defense of interests of actors that mobilize allies in order to strengthen themselves sufficiently to point of being able to influence the path of the controversy.

\section{Acknowledgements}

Conselho Nacional de Desenvolvimento Científico e Tecnológico - CNPq, Coordenação de Aperfeiçoamento de Pessoal de Nível Superior - Capes.

\section{References}

BROOKES, G., Barfoot, P. (2006). Global Impact of Biotech Crops: Socio-Economic and Environmental Effects in the First Ten Years of Commercial Use. AgBio Forum, 9(3).

CALÁS, M.B., Smircich, L. (1999). Past postmodernism? Reflections and tentative directions. Academy of Management Review, 24(4), pp. 649-7I.

CALLON, M., Lascoumes, P. Barthe, Y. (200I). Agir dans un monde incertain: essai sur la democratie technique. Éditions du Seuil, Paris.

Casa Civil/Subchefia para Assuntos Jurídicos, (2005). Mensagem $N^{\circ}$ 167, de 24 de março de 2005. Presidência da República, Brasília

DESCOLA, P. (2005). Par-delà nature et culture. Gallimard, Paris.
DOSI, G., Levinthal, D.A., Marengo, L. (2003). Bridging contested terrain: linking incentive based and learning perspectives on organizational evolution. Industrial and Corporate Change, I2(2), pp.4I3-36.

EMBRAPA SOJA (2003). Tecnologias de produção de soja: região central do Brasil - 2003. [Online] Available at: http://sistemasdeproducao.cnptia.embrapa.br/FontesHTML/ Soja/SojaCentralBrasil2003/importancia.htm [Accessed 22 October 2007].

FREEMAN, C. (1982). The economics of technical change. Frances Pinter Publishing, London.

FREEMAN, C., Soete, L. (1997). The economics of industrial innovation. $3^{\mathrm{a}}$ ed. MIT Press, Mass.

FURTADO, C. (2008). Criatividade e dependência na civilização industrial. Edição Definitiva. Companhia das Letras, São Paulo.

HEBERLÊ, A.L.O. (2005). Significações dos transgênicos na mídia do Rio Grande do Sul. PhD São Leopoldo: Universidade do Vale do Rio dos Sinos.

HINCHEE, M.A.W. et al. (1988). Production of Transgenic Soybean Plants Using Agrobacterium-Mediated DNA Transfer. Nature Biotechnology, 6, pp.915-22.

JAMES, C. (1998). Global Review of Commercialized Transgenic Crops: 1998. ISAAA - Brief 08.

JAMES, C. (2006). Situação global da comercialização das lavouras GM. ISAAA - Brief 35.

KLEBA, J.B. (1998). Riscos e benefícios de plantas transgênicas resistentes a herbicidas: 0 caso da soja RR da Monsanto. Cadernos de Ciência \& Tecnologia, I5(3), pp.9-42.

LATOUR, B. (1997). Nous n'avons jamais été modernes. La Découverte, Paris.

LATOUR, B. (2004). Politiques de la nature. La Découverte, Paris.

LATOUR, B. (2005). La science in action: introduction à la sociologie des sciences. La Découverte, Paris. 
LATOUR, B. (2006). Changer de societé. Refaire de la sociologie. La Découverte, Paris.

LAW, J. (1986). On power and its tactics: a view from the sociology of science. Sociological Review, 34, pp. I-37.

LAW, J. (2000). Networks, ralations, cyborgs: on the social study of technology. On-Line Papers. Centre for Science Studies Lancaster University.

LÖWY, I. (2005). Preface. In Fleck, L. Genèse et development d'un fait cientifique. Les Belles Lettres, Paris.

LUNDVALL, B.A. et al. (2002). National systems of production, innovation and competence building. Research Policy, 3I, pp.2I3-3I.

LUNDVALL, B.A. (1999). National business systems and national systems of innovation. International Studies of Management \& Organizations, 29(2).

MCCABE, D.E. et al. 1988. Stable transformation of soybean (Glycine max) by particle acceleration. Nature Biotechnology, 6, pp.923-26.

Ministério do Meio Ambiente (2007). Biossegurança. [Online] Available at: http://www.mma.gov.br [Accessed: 29 September 2007].

MIRANDA, L.C. (2005). Nova concepção de parcerias na Embrapa. [Online] Available at: http://www.abrasem.com.br [Accessed 22 August 2007].

MMA/Consultoria Jurídica, (2005). (Parecer N57/CONJUR/MMA/2005). Brasília.

MORTARI, R. (2006). Algumas coisas que você sempre quis saber sobre transgênicos. Revista Ciência, Tecnologia e Inovação: Transgênicos passados a limpo, 2(7).

NELSON, R., Rosenberg, N. (1993). National innovation systems: a comparative analysis. Oxford University Press, New York.

NODARI, R.O., Guerra, M.P. (2000). Implicações dos transgênicos na sustentabilidade ambiental e agrícola. História, Ciências, Saúde - Manguinhos, 2(2), Pp. 48I-9I.
Nuffield Council on Bioethics, (2003). The use of genetically modified crops in developing countries: a follow-up discussion paper. [Online] Available at: http://www.nuffieldbioethics.org [Accessed 04 April 2007].

PATEL, R., Torres, R., Rosset, P. (2005). Genetic Engineering in Agriculture and Corporate Engineering in Public Debate. Genetic Engeneering, I I (4).

PELAEZ, V., Albergoni, L., Guerra, M.P. (2004). Soja transgênica versus soja convencional: uma análise comparativa de custos e benefícios. Cadernos de Ciência \& Tecnologia, 2I(2), pp.279-309.

SOUSA JR. G. (2006). Brasil transgênico. Revista Ciência, Tecnologia e Inovação: Transgênicos passados a limpo, 2(7).

WATANABE, E., Nutti, M.R. (2002). Alimentos geneticamente modificados: avaliação de segurança e melhorias de qualidade em desenvolvimento. Revista Brasileira de Milho e Sorgo, I(I), pp. I-I4.

ZERO HORA. Caderno Campo \& Lavoura. 01/01/1998 a $3 I / / 2 / 2003$. 